\title{
Isolation and identification of rhizobial strains from faba bean nodules.
}

\author{
Mona H. A. Hussein ${ }^{2}$; Zaghloul, R.A. ${ }^{1}$; Abou Aly, H.A. ${ }^{1}$; Abdel-Rahman, H.M. ${ }^{1}$ and Abotaleb, H.H ${ }^{2}$ \\ 1- Agric. Microbiology, Agric. Botany Department, Faculty of Agriculture, Benha University, Egypt \\ 2-Agric. Microbiology Dep., Soil Water Environment Research Institute, Agric. Research Center, Giza, Egypt. \\ Corresponding author: Hany.abdelrahman@fagr.bu.edu.eg
}

\begin{abstract}
To maximize of faba bean production in the new reclaimed land in Egypt need to isolate and select of effective rhizobial strains. Thirty rhizobial isolates were collected from the healthy root nodule of faba bean (Vicia faba) grow in different geographic locations and soil properties in Egypt. Morphological studies, nodulation, salinity tolerance, as well as 16S rDNA partial sequence were used for identification and characterization the obtained rhizobial isolates. All tested isolates were short rod, Gram negative and most of them were opaque and high viscosity. According to nodulation, the promising isolates were determined. The most promising isolates tolerated the high $\mathrm{NaCl}$ concentration up to 3.5 and $4 \%$. Moreover the two isolates are 2 is and Nob3 had a positive growth at $4.5 \% \mathrm{NaCl}$ concentration ( $10^{7}$ Rhizobial cell per ml.). Data showed that both Is 2 and Nob 3 isolates were the best isolates where they gave the highest number of nodules and growth characteristics of the two faba bean varieties. The 16S rDNA sequencing results revealed that the nearest bacterial species to our isolate M4 was Rhizobium sp. (KF111868) 94\% identity while, M6 isolate was 99\% identical to Rhizobium rubi (BBJU0100046). The sequence was submitted to NCBI website with accession number Gen Bank: KX639721 and KX639722 respectively.
\end{abstract}

Key words: Isolation, Rhizobia, faba bean, nodules

\section{Introduction}

The seed of legumes has long values of their potential to acquire $\mathrm{N}$ through symbiotic $\mathrm{N}_{2}$-fixation, additionally legumes in the same time proved $\mathrm{N}$ to succeeding crops. Symbiotic nitrogen fixation by legumes plays an important role in reinforcing crop productivity and conserving the fertility of peripheral land and the smallholder system of the arid and simiarid tropics, it expected that the importance of legumes and symbiotic nitrogen fixation will continue to increase the development of national sustainable agriculture more than $50 \%$ of nitrogen fertilizers are somehow last thought different processes which not only represent a cash loss to the farmers but also consequent by polluted the environment. The major step toward maximum symbiotic $\mathrm{N}_{2}$-fixation technology is the increment of land area under legumes and enhances their seeds and fodder yield thought overcoming environmental and productivity condition problems which limit symbiotic $\mathrm{N}_{2}$ fixation and legume productivity, however, symbiotic $\mathrm{N}_{2}-$ fixation by legumes is strongly in fenced by the environmental stress conditions as drought, salt stress, water deficiency, soil acidity, temperature and low phosphorus, Zahran et al. (1999\&2001), Fauvort and Michieis, (2008), and Zheng et al.,(2009). Bacteria belonging to the Allorhizobium Azorhizobium, Bradyrhizobium, Mesorhizobium, Rhizobia Zakhia anddelajudie, (2001). The increased use of rhizobia inoculate should help in achieving increased yields of food and forage legume crops in a more economical way, so, much attention is required to discover new leguminous species as well as rhizobial strains with high production capabilities and high symbiotic performance. In Egypt, faba bean (Vicia faba L.) is one of the most important leguminous crops and its importance comes from the high value of seed protein content that is used for human and animal consumption. In addition, it's one of the excellent suppliers of soil nitrogen to the subsequent crops, The estimated average amount of $\mathrm{N}_{2}$-fixed by faba bean is $135 \mathrm{Kg} \mathrm{h}^{-1}$ while it's 97,83 , 68 and $4 \mathrm{~kg} \mathrm{~h}^{-1}$ for chickpea, lentil, peanut and soybean plant respectively. For this, more effective strains and isolates of rhizobia will have to be discovered and these super competitive bacteria will be more acceptable to their particular hostess than those currently in use. The present work aims to isolate and identify rhizobial isolates from faba bean plants grown under different soil condition of Egypt to improve the faba bean productivity and sustaining the fertility of soil.

\section{Materials and Methods}

\section{Collection and isolation of Rhizobial isolates:}

Thirty representative sites from ten Egyptian governorates as presented in Table (1) and Fig (1).Rhizobial isolates collected from the root nodule of faba bean (Vicia fabaL.) plants. Rhizobia were isolated from root nodules according to the methods described by Somasegaran and Hoben (1994). Nodules were surface sterile in $3 \% \mathrm{NaOCl}$ for $4 \mathrm{~min}$, rinsed five times in the sterile water and cursed in a drop of sterile water on sterilized petri dish. A loopful 
of the cursed nodule was streaked on yeast extract mannitol agar (YEMA) medium containing congored pigment to ensure the purity of growth, then the plats were incubated at After 3-7 days, individual colonies appearing over this proved were re-streaked onto YEMA medium and stored at $42 \mathrm{C}^{\circ}$ until the time of processing.

Table1. Locations and codes of the new rhizobial isolates

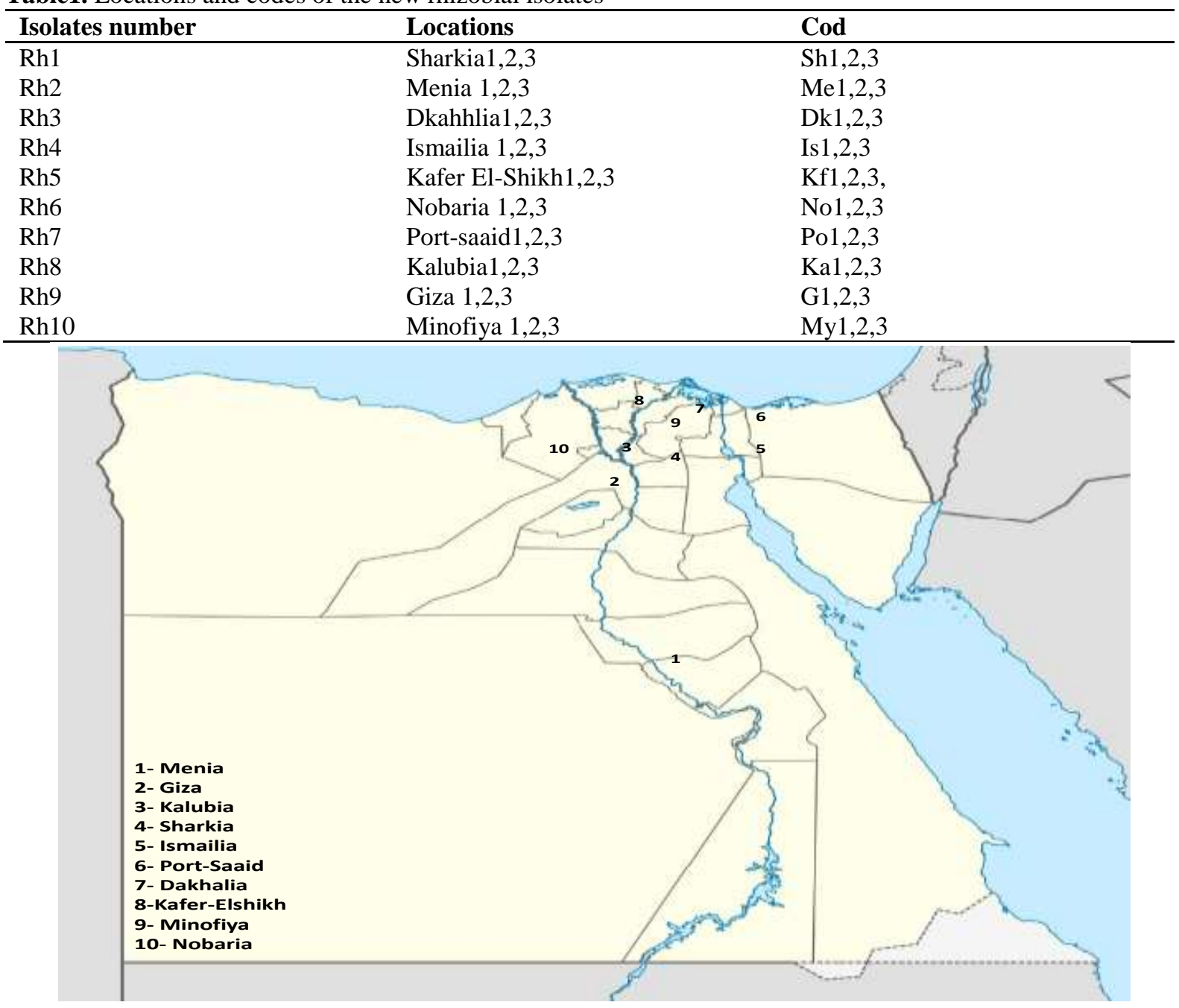

Fig. (1) Ten locations for Rhizobial Faba bean isolates

\section{Laboratory experiments}

2.1 Morphological characteristics of rhizobial isolates

Identical pure colonies of rhizobial isolates were examined microscopically to determine cell shape and Gram reaction. Whereas motility was tested in liquid culture. Morphology of colonies were determined for each isolates which streaked on solid YEMA medium and incubated for 3 days at $28 \mathrm{C}^{\circ}$ using binuclear microscope to evaluate colony size, Transparency and viscosity, according to Somasegaran and Hoben 1994.

\subsection{Salinity Tolerance}

Gradient salt concentrations of $(0.0,0.5,0.75,1.0$, $1.5,2.0,2.5,3.0,3.5,4.0,4.5,5.0$ and $5.5 \% \mathrm{NaCl}$ were prepared in YEMA broth to evaluate the tolerance of obtained rhizobial isolates to salinity compared to reference Rhizobium strains namely
ICARDA44 and ARC202, the two references rhizobia strains were kindly provided by Biofertilizer Production Unit, Agric. Microbiology Dep., Soil Water environment Research Institute (SWERT), Agric. Research Center (ARC), Giza, Egypt. Different concentrations of $\mathrm{NaCl}$ were inoculated by $1 \mathrm{ml}$ containing $10^{9}$ cfuof new rhizobia cultures and inoculated at $28 \mathrm{C}^{\circ}$ for 144 hours and counting the appearances colonies on Petridishes contain YMA medium.

\section{Greenhouse experiment}

Two pot experiments were carried under given condition of greenhouse of SWERI, ARC, Giza, Egypt to select and study the more potent isolate.

\subsection{The most promising isolates (MPI)}

A pot experiment was laid out to evaluate the ability of the 30 rhizobial isolates (10 locations x 3 
isolates), which grow well on YEMA medium to form nodules on roots of faba bean variety Giza 843 which kindly provided by the Department of Legume Crops, Field Research Institute, ARC. Seeds were planted in plastic potsof $30 \mathrm{~cm}$ diameter field with $5 \mathrm{~kg}$ sterilized sandy soil by using $\mathrm{NaOCl} 2.5 \%$ then washed several times with distilled water. Physical and chemical properties of soil used are presented in Table (2) according to Jackson) 1973). The Bold recommended doses of phosphorus and potassium ( $\mathrm{P}$ and $\mathrm{K}$ ) fertilizer were applied planting (equal $1 \mathrm{gm}$ and $0.25 \mathrm{~g}$ per pot from super phosphate $\left(15.5 \% \mathrm{P}_{2} \mathrm{O}_{5}\right)$ and potassium sulphate $\left(48 \% \mathrm{~K}_{2} \mathrm{O}\right)$. Faba bean seeds were inoculated three times $(0,15$ and 21 days) from planting with $10 \mathrm{ml}$ per pot from rhizobial cultures for each isolate as well as the two reference rhizobial stains ICARDA441 and ARC202with bacterial load $10^{9}$ cell per ml. Samples were picked up after 45 days of planting to determine number of nodules (No. per plant) as well as nodules dry weight (mg per plant).The most premising isolate (MPI) from each governorates were determined.

Table 2. Some physicochemical properties of used soil.

\begin{tabular}{|c|c|}
\hline Property & Values \\
\hline \multicolumn{2}{|l|}{ Particle size distribution (\%) } \\
\hline Sand $\%$ & 86.30 \\
\hline Silt $\%$ & 10.17 \\
\hline Clay $\%$ & 3.35 \\
\hline Texture gade & Sandy \\
\hline \multicolumn{2}{|l|}{ Physical properties: } \\
\hline \multicolumn{2}{|l|}{ Saturation percent ( S. p) \% } \\
\hline $\mathrm{pH}$ & 13 \\
\hline E.C. $\mathrm{dS} / \mathrm{m}$ & 7.58 \\
\hline Organic matter O.M \% & 0.57 \\
\hline Total nitrogen T.N \% & 0.40 \\
\hline Chemical properties: & 0.021 \\
\hline \multicolumn{2}{|l|}{ Soluble cations:( meq. $1^{-1}$ ) } \\
\hline $\mathrm{Ca}^{++}$ & 1.58 \\
\hline $\mathrm{Mg}^{++}$ & 0.82 \\
\hline $\mathrm{Na}^{+}$ & 0.64 \\
\hline $\mathrm{K}^{+}$ & 1.95 \\
\hline \multicolumn{2}{|l|}{ Soluble anions: ( meq. $1^{-1}$ ) } \\
\hline CO3-- & 0.00 \\
\hline $\mathrm{HCO}^{-}$ & 0.62 \\
\hline $\mathrm{CI}^{-}$ & 0.76 \\
\hline $\mathrm{SO}^{--}$ & 3.61 \\
\hline
\end{tabular}

\subsection{Screening for more potent isolates}

A pot experiment was designed to study the ability of tested the most promising isolates (10 isolates) to form nodules on faba compared with the two references rhizobial strain (ICARDA 441\&ARC 202) according to method described by Broughton and Dilworth (1971).Two faba bean various (Giza843 and Giza3) were used. Pure cultures of rhizobial isolates and reference strains were prepared by inoculating YEMA broth medium from $24 \mathrm{hr}$. old slant. Liquid cultures were incubated on a rotary shaker at $28 \mathrm{C}^{\circ}$ for $48 \mathrm{hr}$. The soil was sterilized by $\mathrm{NaOCl} 2.5 \%$ then washed several times with distilled water, air dried and distributed into $10 \mathrm{~kg}$.portions in plastic pots $40 \mathrm{~cm}$ diameter. Five seeds from each faba bean variety were sown in each pot and irrigated with $\mathrm{N}$-free nutrient solution to reach $60 \%$ water holding capacity. Inoculation applied three times 0,15 , and 21 days after plating at the rate of $10 \mathrm{ml}$ suspension form the representative isolates and strains containing $10^{9}$ cfuper ml. Plant simples were taken after 75 days from planting to determine number of nodules per plant, nodules dry weight (mg/plant), plant dry weight (g/plant) and plant $\mathrm{N}$-content (mg/plant).

\section{Identification of rhizobial isolate16s rRNA}

DNA was extracted from bacterial cultures using SDSICTAB analysis and phenol /chloroform extraction according to method. Sequence analysis of 16s RNA and Subsequent Blast N analysis indicated that the majority of isolated strains were livened by Ismail et al, (2013).

\subsection{DNA isolation extraction}

For PCR amplifications, the bacterial genomic DNA was extracted from inoculated LB broth media with bacterial isolate and incubated overnight at $37 \mathrm{C}^{\circ}$ with shaking. A $5 \mathrm{ml}$ of the bacterial suspension was centrifuged. Following discarding the supernatant, the pellet was washed three times with $1 \mathrm{ml}$ TE buffer. The pellet was re-suspended with $500 \mu \mathrm{l}$ TE buffer. A 10 $\mu 1$ proteinase $\mathrm{K}(20 \mathrm{mg} / \mathrm{ml}), 20 \mu 1$ lysozyme $(50 \mathrm{mg} / \mathrm{ml})$ and $100 \mu 1 \quad 10 \%$ SDS were added to the cell suspension. The bacterial cell suspension was incubated overnight. $100 \mu \mathrm{l} 5 \mathrm{M} \mathrm{NaCl}$ and $100 \mu 110 \%$ $\mathrm{CTAB}$ were added and well mixed. The mixture was 
incubated at $70 \mathrm{C}^{\circ}$ for thirty minutes, then was incubated on ice for 10 minutes. The tubes were centrifuged at high speed for 15 minutes. The upper phase - should not be viscous - transferred to $1.5 \mathrm{ml}$ clean microcentrifuge tube and equal volume from phenol chloroform isoamyl25:24:1 was added and mixed well by inverting the tubes. The tubes were centrifuged at $15000 \mathrm{rpm}$ for $15 \mathrm{~min}$. The upper phase was transferred to clean microcentrifuge tubes and an equal volume of chloroform-isoamyl24:1 were added and centrifuged at $15000 \mathrm{rpm}$ for $15 \mathrm{~min}$. The upper phase was transferred to clean microcentrifuge tube and double volume of absolute ethanol was added and incubated overnight at $-20 \mathrm{C}^{\circ}$. For increasing the DNA yield $50 \mu 15 \mathrm{M}$ sodium acetate was added. The tubes were centrifuged at high speed for $20 \mathrm{~min}$. Finally, the DNA pellet washed three times using $1 \mathrm{ml} 70 \%$ ethanol, then the DNA pellet was resuspended in 50 $\mu 1$ sterilized TE Buffer and stored at $-20 \mathrm{C}^{\circ}$ for further use.

\section{2 $\mathrm{PCR}$ reaction}

PCR analysis was performed using 16srRNA gene. The primers used were universal 27F (5'AGAGTTTGGATCMTGGCTCAG-3') and 1492R (5'-CGGTTACCTTGTTACGACTT-3'). The PCR reaction was selectively amplified in $50 \mu$ reaction mixtures composed of $0.4 \mu \mathrm{M}$ of each primer, $400 \mu \mathrm{M}$ of dNTP mix, $5 \mu \mathrm{l}$ of 10x PCR reaction buffer, $2 \mathrm{mM}$ $\mathrm{MgCl}_{2}, \quad 2.5$ units from TAKARA Taq DNA polymerase (Cat. \#:R001AM) and1 $\mu \mathrm{g}$ DNA. The amplification conditions on a master cycler (Eppendorf) were as follows: initial denaturation step at $950 \mathrm{C}$ for $3 \mathrm{~min}, 35$ cycles of amplification $\left(95 \mathrm{C}^{\circ}\right.$ for $50 \mathrm{sec}, 52 \mathrm{C}^{\circ}$ for $1 \mathrm{~min}$ and $72 \mathrm{C}^{\circ}$ for $1 \mathrm{~min}$ ), and followed by a final extension at $72 \mathrm{C}^{\circ}$ for $10 \mathrm{~min}$. Amplified PCR product was analyzed by electrophoresis on $1.2 \%$ agarose gel stained with Ethidium bromide using GeneRuler ${ }^{\mathrm{TM}} 1 \mathrm{~kb}$ DNA ladder (Cat. SM0313), then visualized under UV Transilluminator.

\section{5-Statistical analysis}

Results were statically analyzed by the least significant differences test (LSD) at P 0.05 by using (MSTAT) microcomputer statistical proGram according to Steel and Torrie, (1980).

\section{Results and Discussion}

\section{1-Isolation and characterization of Rhizobia}

Thirty rhizobial isolates were recovered from the root nodules of faba bean (Vicia faba L.) grown in different geographic locations, soil properties and climatic condition in Egypt. Pure colonies of rhizobial isolates were microscopically examined to determine cell shape and size, Gram stain reaction and motility in liquid culture .Colony morphology of rhizobial isolates was studied to determine the opacity and viscosity by using binoculars. The data in Table (3) show that all rhizobial isolates tested had fast growth on YEMA medium, non-capsulated, short rod, Gram negative and motile. Cell size ranged from 1 to $4 \mathrm{Mm}$ among all tested isolates. The most isolates colonies are opaque while isolates from locations Ismailia, Nobaria, and port-saaid were translucent.

Table 3. Some morphological characteristics of Rhizobial isolates .

\begin{tabular}{|c|c|c|c|c|c|c|c|}
\hline \multirow[b]{2}{*}{$\begin{array}{l}\text { Source of } \\
\text { isolates (origin) }\end{array}$} & \multirow[b]{2}{*}{$\begin{array}{l}\text { Code of } \\
\text { Isolates }\end{array}$} & \multicolumn{3}{|c|}{ Cell morphology } & \multicolumn{2}{|c|}{ Morphological of colony } & \multirow[b]{2}{*}{ Viscosity } \\
\hline & & Shape & $\begin{array}{l}\text { Gram } \\
\text { Reaction }\end{array}$ & Motility & $\operatorname{Size}(\mathbf{m m})$ & Transparency & \\
\hline Sharkia & Sh1,2,3 & $\begin{array}{c}\text { Short } \\
\text { rod }\end{array}$ & Negative & + & $1-2$ & Opaque & High \\
\hline Menia & M1,2,3 & $\begin{array}{c}\text { Short } \\
\text { rod }\end{array}$ & Negative & + & $1-2$ & Opaque & High \\
\hline Dkahleia & Dk1,2,3 & $\begin{array}{l}\text { Short } \\
\text { rod }\end{array}$ & Negative & + & $2-3$ & Opaque & High \\
\hline Ismailia & Is1,2,3 & $\begin{array}{l}\text { Short } \\
\text { rod }\end{array}$ & Negative & + & $2-4$ & Translocation & V. High \\
\hline Kafer El-shikh & Kf1,2,3 & $\begin{array}{l}\text { Short } \\
\text { rod }\end{array}$ & Negative & + & $2-4$ & Opaque & High \\
\hline Nobaria & No1,2,3 & $\begin{array}{l}\text { Short } \\
\text { rod }\end{array}$ & Negative & + & $1-2$ & Translocation & V. High \\
\hline Port-said & Po1,2,3 & $\begin{array}{l}\text { Short } \\
\text { rod }\end{array}$ & Negative & + & $1-2$ & Translocation & Low \\
\hline Kalubia & Ka1,2,3 & $\begin{array}{l}\text { Short } \\
\text { rod }\end{array}$ & Negative & + & $1-2$ & Opaque & Low \\
\hline Giza & Gi1,2,3 & $\begin{array}{l}\text { Short } \\
\text { rod }\end{array}$ & Negative & + & $1-2$ & Opaque & High \\
\hline Menofiya & Me1,2,3 & $\begin{array}{c}\text { Short } \\
\text { rod }\end{array}$ & Negative & + & $1-2$ & Opaque & Low \\
\hline
\end{tabular}


Three of the tested isolates recorded in low viscosity while the other isolates gave high or very high viscosity. The obtained data are in harmony with data reported by Bergey's Manual of Systematic Bacteriology (2005), who reported that the characteristics of rhizobia were sort rots (0.5-1.0 $\mathrm{x} 1.2-3.0 \mathrm{Mm}$ ), no spore, forming, Gram negative reaction and motile by 1-6 peritrichous flagella. Colonies are usually white or beige, crawler, convex, semi-trans lucent or opaque raised and mucilaginous, usually $2-4 \mathrm{~mm}$ in diameter 3-5 days on YEMA medium.

\section{2-The most promising isolates (MPI):}

The 30 selected isolates were tested of their ability to form nodules on roots of faba bean plant variety (Giza 843). The obtained results in Table (4)clearly show ten of the 30 isolates (one from location) namely most promising isolates (MPI) were determined according to data in Table(2). Ten of isolates namely Sh2, Me1, Dk3, Is2, Kf1, No3, Po1, Ka 2, G 2 and Mf1were recorded the higher nodule number per plants as well as nodule dry weight, moreover, the isolates Is 2 and No3 gave the highest nodule number and nodule dry weight and these values were (63and 57) and (574 and 374) for nodule number and nodule dry weight, respectively, as compared to other tested isolates.

Table 4. Number and dray weight of nodules of the most promising isolates (MPI) formed on the roots of faba bean plant nodules variety (G.843) after 45 days from planting.

\begin{tabular}{|c|c|c|c|}
\hline $\begin{array}{l}\text { Promotes } \\
\text { Treatments }\end{array}$ & Isolates & $\begin{array}{l}\text { Number of nodules } \\
\text { (no) plant-1 }\end{array}$ & $\begin{array}{c}\text { Dry weight of nodules } \\
\text { (mgplant-1) }\end{array}$ \\
\hline \multirow{3}{*}{ Sharkia } & Sh1 & 23 & 131 \\
\hline & *Sh2 & 28 & 178 \\
\hline & Sh3 & 17 & 85 \\
\hline \multirow[t]{3}{*}{ Menia } & $*$ Me1 & 31 & 285 \\
\hline & Me2 & 24 & 163 \\
\hline & Me3 & 28 & 174 \\
\hline \multirow[t]{3}{*}{ Dkahlia } & Dk1 & 31 & 241 \\
\hline & Dk2 & 29 & 213 \\
\hline & $*$ Dk3 & 37 & 321 \\
\hline \multirow[t]{3}{*}{ Ismailia } & IS1 & 49 & 283 \\
\hline & $* * \mathbf{I S 2}$ & 63 & 574 \\
\hline & IS3 & 52 & 361 \\
\hline \multirow[t]{3}{*}{ Kafer El-shikh } & $* \mathbf{K f 1}$ & 14 & 113 \\
\hline & Kf2 & 11 & 69 \\
\hline & Kf3 & 15 & 84 \\
\hline \multirow[t]{3}{*}{ Nobaria } & No1 & 43 & 235 \\
\hline & No2 & 53 & 307 \\
\hline & **No3 & 57 & 374 \\
\hline \multirow[t]{3}{*}{ Port-saaid } & *Po1 & 28 & 193 \\
\hline & Po2 & 22 & 163 \\
\hline & Po3 & 17 & 131 \\
\hline \multirow[t]{3}{*}{ Kalubia } & Ka1 & 35 & 287 \\
\hline & $\mathbf{K a 2}$ & 43 & 371 \\
\hline & Ka3 & 39 & 313 \\
\hline \multirow[t]{3}{*}{ Giza } & G1 & 22 & 195 \\
\hline & $* \mathbf{G} 2$ & 35 & 305 \\
\hline & G3 & 28 & 237 \\
\hline \multirow[t]{3}{*}{ Menofia } & *My1 & 35 & 305 \\
\hline & My2 & 28 & 256 \\
\hline & My3 & 23 & 211 \\
\hline
\end{tabular}


3-The effect of saline concentrations $(\mathrm{NaCl} \%)$ :

Data in Table (5) summarized the effect of various $\mathrm{NaCl}$ concentrations (from 0.0 to $5.5 \%$ ) on the ten selected rhizobial isolates (MPI). The all tested isolates grew well up to $1.5 \% \mathrm{NaCl}$ concentration while their growth varied from $\mathrm{NaCl}$ concentration on $2.0 \%$ to $4.5 \%$. At $5.0 \% \mathrm{NaCl}$ concentration the growth of all tested isolates including reference strains (ICARDA441 and ARC202) were completely stopped. Rhizobium reference strain (ICARDA441) was the most sensitive one and had poor growth at
2.5\% $\mathrm{NaCl}$ concentration. On the other hand, both rhizobial isolates Is3 and No3 showed the most tolerant against $\mathrm{NaCl}$ concentrations among all tested rhizobial isolates and recorded growth until $4.5 \% \mathrm{NaCl}$. This finding is in line with the report of Keneni et al. (2010) and Blal et al. (2013) who found that rhizobial isolates were not completely inhibited by $5 \%$ of $\mathrm{NaCl}$ concentration and they added the rhizobial growth was not effected by low and moderate levels of salinity ( $\mathrm{NaCl} \%$ concentration).

Table 5. The effect of saline concentrations $(\mathrm{NaCl} \%)$ on rhizobial isolates growth.

\begin{tabular}{|c|c|c|c|c|c|c|c|c|c|c|c|c|c|}
\hline \multirow[b]{2}{*}{ Location } & \multicolumn{13}{|c|}{$\mathrm{NaCl} \%$} \\
\hline & 0.0 & 0.5 & 0.75 & 1.0 & 1.5 & 2.0 & 2.5 & 3.0 & 3.5 & 4.0 & 4.5 & 5.0 & 5.5 \\
\hline Sh.2 & +++ & +++ & +++ & +++ & +++ & +++ & ++ & + & + & - & - & - & - \\
\hline Me.1 & +++ & +++ & +++ & +++ & +++ & +++ & ++ & ++ & + & - & - & - & - \\
\hline Dk.3 & +++ & +++ & +++ & +++ & +++ & +++ & +++ & ++ & + & - & - & - & - \\
\hline Is. 2 & +++ & +++ & +++ & +++ & +++ & +++ & +++ & ++ & + & + & + & - & - \\
\hline Kf.1 & +++ & +++ & +++ & +++ & +++ & +++ & ++ & + & + & + & - & - & - \\
\hline Nop.3 & +++ & +++ & +++ & +++ & +++ & +++ & +++ & ++ & ++ & + & + & - & - \\
\hline Po.1 & +++ & +++ & +++ & +++ & +++ & +++ & ++ & ++ & + & + & - & - & - \\
\hline Ka. 2 & +++ & +++ & +++ & +++ & +++ & ++ & + & + & - & - & - & - & - \\
\hline Gi.2 & +++ & +++ & +++ & +++ & +++ & ++ & ++ & + & - & - & - & - & - \\
\hline Mf.1 & +++ & +++ & +++ & +++ & +++ & ++ & + & + & - & - & - & - & - \\
\hline ICARDA441 & +++ & +++ & +++ & +++ & +++ & + & + & - & - & - & - & - & - \\
\hline ARC202 & +++ & +++ & +++ & +++ & +++ & ++ & ++ & + & + & - & - & - & - \\
\hline
\end{tabular}

( - ) No growth + Poor growth $\left(10^{7} \mathrm{CFU} \mathrm{m}{ }^{-1}\right)++$ Medium growth $\left(10^{7} \mathrm{CFU} \mathrm{ml}{ }^{-1}\right)+++$ good growth $\left(10^{9} \mathrm{CFU}\right.$ $\left.\mathrm{ml}^{-1}\right)$

Rhizobia reference strain (ICARDA441) was the most sensitive one and had poor growth at $2.5 \% \mathrm{NaCl}$ concentration. On the other hand, both rhizobial isolates Is 3 and No3 showed the most tolerant against $\mathrm{Na}$ concentrations among all tested rhizobial isolates and recorded growth until $4.5 \% \mathrm{Nacl}$. This finding is in line with the report of Keneni et al. (2010) and Belal et al. (2013) who found thus rhizobial isolates were not completely inhibited by $5 \%$ of $\mathrm{NaCl}$ concentration and they also added that the rhizobial growth was not affected by low levels of salinity ( $\mathrm{NaCl} \%$ concentration).

\section{Selection of more potent isolates}

The number of nodules, dry weight of nodules, dry weight plant dry weight as well as plant nitrogen content of (MPI) selected rhizobial isolates with the two faba bean various stress condition, Giza 843 Cortland variety) and Gize3 (sensitive variety) were presented in Table (6). Data in Table (6) emphasized that there are significant differences found among all tested isolates and strains with two faba bean varieties used at nodules number and dry weight as well as plant dry weight and plant $\mathrm{N}$-content. The obtained results showed that local isolate Is 2 recorded the highest values as compared to other tested isolates and strains for nodules number, nodules dry weight, plant dry weight and plant nitrogen content and these values were (75 and 63), (634 and 575mg/plant), (3.18 and $2.95 \mathrm{~g} / \mathrm{plant})$ and (102.26 and $92.89 \mathrm{mg} / \mathrm{plant})$ for nodule number, nodules dry weight, plant dry weight and plant nitrogen content for faba bean varieties G843 and G3, respectively. The responding figures for isolate No3 were (96 and 51) (493 and 397mg/plant), (2.93 and 2.88 plant/plant) and (81.47 and 87.90 $\mathrm{mg} /$ plant).In this respect the obtained results are in harmony with Digvijay et al. (2011) and Elzanaty $\boldsymbol{e t}$ al. (2005) who reported that the native rhizobial 
strains gave positive response between plant-bacteria relationship as well as eco- soil systems and they added to get new rhizobial strains.

Table 6. Nodule number, Plant dry weight and Plant N content of MPI rhizobia inoculum with two faba bean variety at 75 day of planting.

\begin{tabular}{|c|c|c|c|c|c|c|c|c|c|c|c|c|}
\hline \multirow{2}{*}{$\begin{array}{l}\text { Promotes } \\
\text { Treatments }\end{array}$} & \multicolumn{3}{|c|}{$\begin{array}{c}\text { Number of } \\
\text { nodules (no) } \\
\text { plant }^{-1}\end{array}$} & \multicolumn{3}{|c|}{$\begin{array}{c}\text { Dry weight of } \\
\text { nodules (mg.plant }{ }^{-1} \text { ) }\end{array}$} & \multicolumn{3}{|c|}{$\begin{array}{l}\text { Plant dry weight (g } \\
\text { plant }^{-1} \text { ) }\end{array}$} & \multicolumn{3}{|c|}{$\begin{array}{l}\text { Plant N- content (mg } \\
\left.\text { plant }^{-1}\right)\end{array}$} \\
\hline & V1 & V2 & $\mathrm{X}^{-}$ & V1 & $\mathrm{V} 2$ & $\mathrm{X}^{-}$ & V1 & $\mathrm{V} 2$ & $\mathrm{X}^{-}$ & V1 & V2 & $\mathrm{X}^{-}$ \\
\hline Sh.2 & 41 & 35 & 38 & 368 & 267 & 318 & 2.35 & 2.16 & 2.26 & 73.36 & 64.58 & 68.97 \\
\hline Me.1 & 43 & 37 & 40 & 375 & 281 & 328 & 2.89 & 2.79 & 2.84 & 90.22 & 81.09 & 85.66 \\
\hline Dk.3 & 36 & 40 & 38 & 263 & 317 & 290 & 2.70 & 2.64 & 2.67 & 84.29 & 77.41 & 86.85 \\
\hline Ts. 2 & 75 & 63 & 69 & 634 & 575 & 605 & 3.18 & 2.95 & 3.07 & 102.26 & 92.89 & 97.58 \\
\hline Kf.1 & 46 & 37 & 42 & 398 & 299 & 349 & 2.60 & 2.55 & 2.58 & 79.44 & 76.00 & 77.82 \\
\hline Nop.3 & 96 & 51 & 60 & 493 & 397 & 445 & 2.93 & 2.88 & 2.91 & 81.47 & 87.90 & 84.69 \\
\hline Po. 1 & 39 & 34 & 37 & 287 & 273 & 280 & 2.30 & 2.13 & 2.22 & 63.70 & 61.94 & 62.82 \\
\hline Kf.1 & 46 & 51 & 49 & 377 & 403 & 390 & 2.43 & 2.23 & 2.33 & 65.86 & 69.61 & 67.74 \\
\hline GI.2 & 40 & 40 & 40 & 388 & 339 & 364 & 2.20 & 2.21 & 2.21 & 61.67 & 63.92 & 62.80 \\
\hline Mf.1 & 36 & 28 & 32 & 270 & 175 & 223 & 3.02 & 2.75 & 2.89 & 84.28 & 75.14 & 79.71 \\
\hline ICARDA441 & 44 & 49 & 47 & 350 & 389 & 370 & 2.69 & 2.39 & 2.54 & 79.30 & 71.68 & 75.49 \\
\hline ARC202 & 42 & 51 & 56 & 297 & 453 & 375 & 2.97 & 2.45 & 2.71 & 82.71 & 76.81 & 79.76 \\
\hline $\mathrm{X}^{-}$ & 46 & 43 & - & 375 & 347 & - & 2.69 & 2.51 & - & 79.06 & 74.91 & - \\
\hline LSD $0.5 \%$ & 17 & 8 & - & 87 & 56 & - & 0.42 & 0.37 & - & 23.11 & 18.27 & - \\
\hline
\end{tabular}

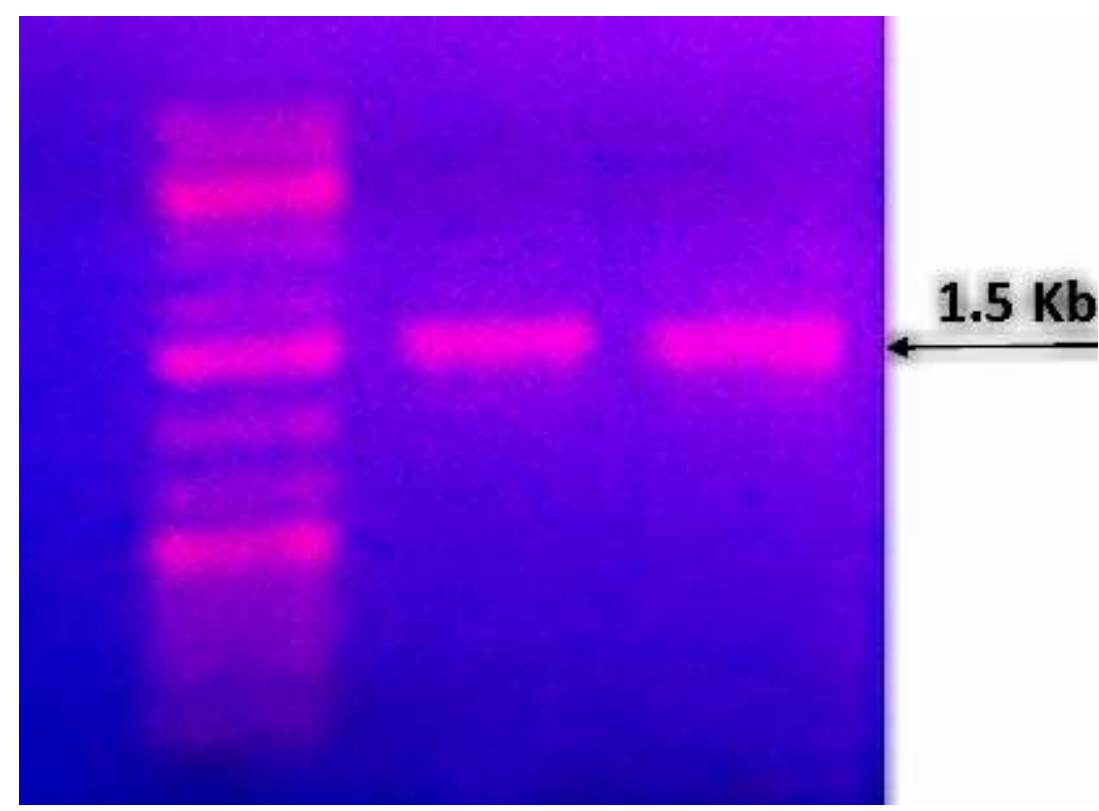

(Fig.2): PCR products for 16s rRNA partial-length gene $(1500 \mathrm{bp})$ of the obtained Rhizobium isolates. M refers to Gene Ruler TM 1kb DNA ladder (Cat. \#: SM0313).

The obtained results clearly showed that with the two faba bean varieties tested, the superior of the local rhizobial isolates as compared to applied the reference Rhizobium strains was noticed. This data are in agreement with O' Hara,et al.(2002), Mnaekuet al. (2009), Workalemahu(2009) and Zahran et al. (2012)who reported that the isolated native rhizobial strains are of good traits, e.g. tolerant to high salt levels, have the ability to form root nodules in high number as well as to induce host plants to give good vegetative growth and yield. From the abovementioned data, the two rhizobial isolates Is2 and No3 were selected for, 16s rRNA gene sequencing.

\section{5- DNA and phylogenetic analysis:}

The obtained PCR amplified fragment for $16 \mathrm{~S}$ rRNA gene was $\approx 1500$ bp as shown in (Fig.4).Search of the gene bank nucleotide database using the blast-n algorithm revealed significant math's (high score and 
low e-value)with the gene sequence of isolate Is2 (M4) was 1261nt and sequence of isolate Nu3 (M6)was 1218nt. The sequence was submitted to NCBI website with accession number GenBank: KX639721 and KX639722 respectively
According to the comparison of our isolates against gene bank data bases, our sequence correspond 16S ribosomal RNA gene. M4 isolates were 94\% identical to Rhizobium sp (KF111868) while, M6 isolates were $99 \%$ identical to Rhizobium rubi (BBJU0100046) (Fig.3\&4).
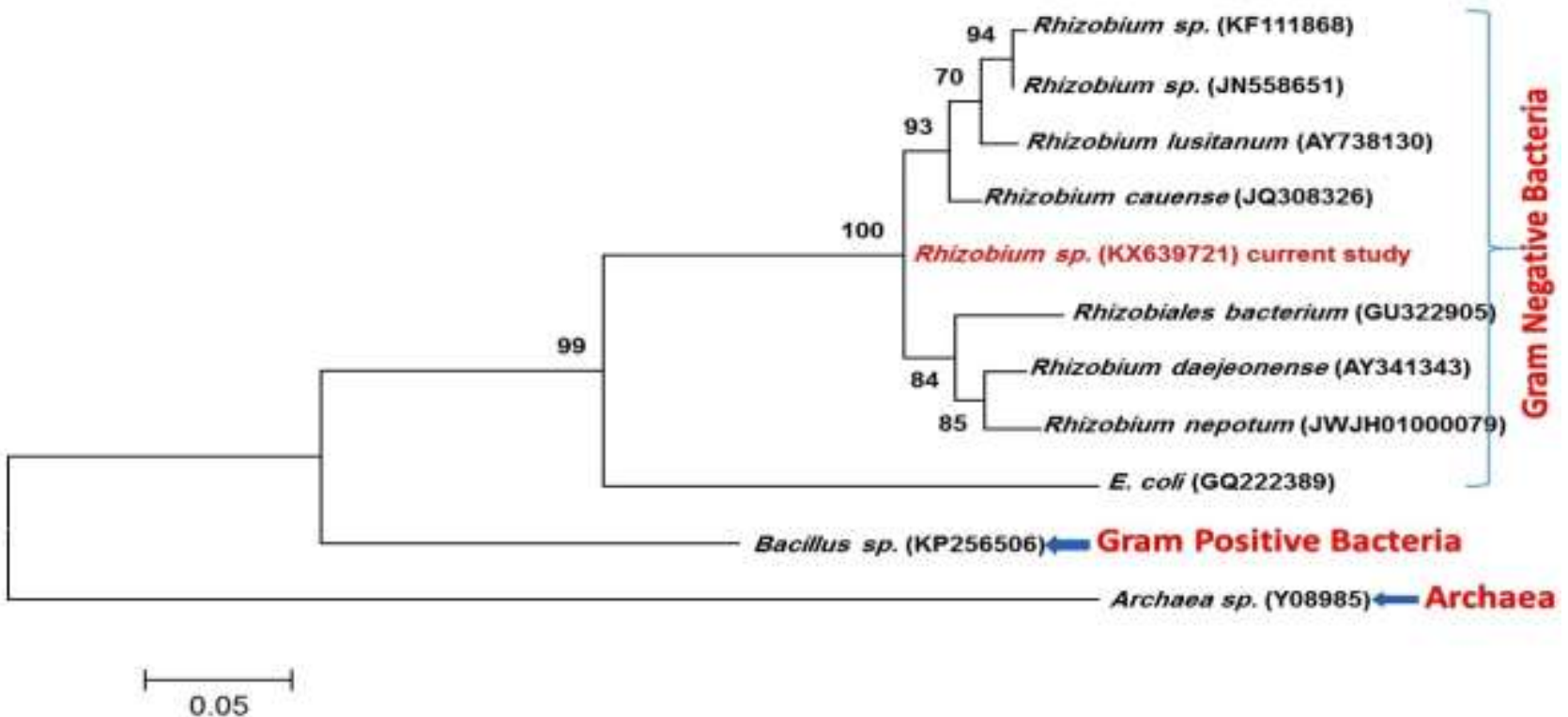

Fig.(3):Neghbour-Joining phylogenetic tree showing relationship between isolate Is2 (M4) and the type strains of rerated species.

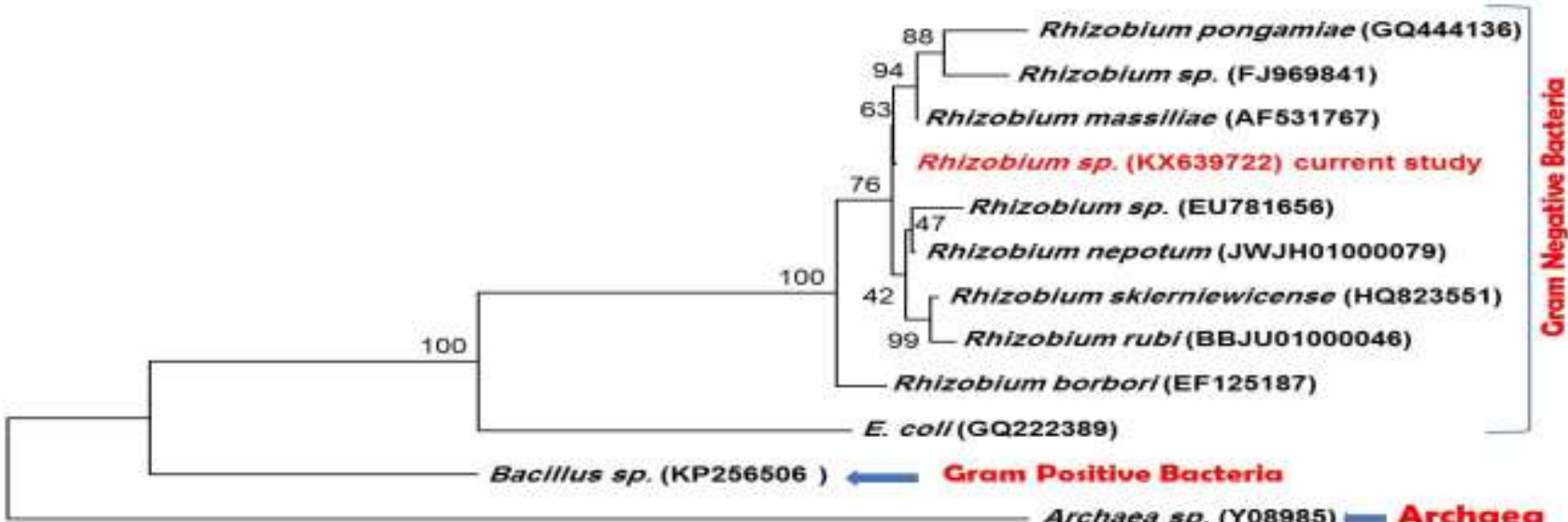

Archaed sp. (Y08985) $=$ Archaec

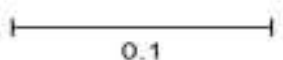

Fig. 4. Neighbour-Joining phylogenetic tree showing relationship between isolate Nub.3 (M6) and the type strains of related species.

\section{Conclusion}

The results from this study concluded that both integrated traditional and molecular characterization approaches for obtaining new rhizobial isolates from different geographic regions soils.

Moreover, it could be recommended that it should be interesting the use of new effective rhizobial isolates to promote plant growth especially under salinity stress that increase crop production, decrease production costs and reduce environmental pollution.

\section{References}

Belal, E. B.; Hassan, M. M. and El-Ramady, H. R. (2013). Phylogenetic and characterization of salttolerant rhizobial strain nodulating faba bean plants. African Journal of Biotechnology; 2013. 12(27):4324-4337. 
Bergey's Manual of Systematic Bacteriology (2005), Volume tow, the proteobacteria partec, Alpha; Beta, Delta;and Epsilon protcobacteria .Pp 325.340.

Broughton, W.J. and Dilworth, M.J.(1971) Control of leghaemoglobin synthesis in snake beans. Biochem. J.125, 1075-1080.

DigvijayPanday,Peter Schumann and Subrata K. Das. (2011). Rhizobium pusense sp., isolated from the rhizosphere of chickpea (Cicerarietinum L.). Internat journal of Systematic and Evolution Microbiology (2011),61,2632-2639; Dol 10.1099/ijs.0.028407-0

Elzanaty AM, Hewedy OA, Nagaty HH and AbdElbary MI.(2005) . Molecular and Biochemical Characterization of Some Egyptian Genotypes. Bioengineering \& Biomedical Science; $\quad 5: 1 \mathrm{http}: / /$ dx.doi.org/10.4172/21559538.1000145

Fauvart M.Michiels J(2008). Rhizobial secreted protins as deteminants of host specificity in the rhizobium legume symbiosis FEMS Microbol.lett 285.1-9.

Ismail M, El-Zanatay AM, RA Eissa, Hewedy OA (2013). Genetic Diversityof Rhizobium leguminosarum as Revealed by $16 \mathrm{~S}$ rRNA Gene Sequence. American-Eur. J Agric Environ Sci 13: 797-801.

Jackson M.l. (1973). "Soil Chemical Analysis" Prentice - Hall India Private Limited, New Delhi,38-251.

Keneni, A., F. Assefa and Prabu,P. C. (2010).Characterization of acid and salttolerantEmir. J. Food Agric. 2013. 25 (2): 102108http://www.ejfa.info/

Mnalku A., Gebrekidan H. and Assefa F. (2009). Symbiotic effectiveness and characterization of Rhizobium strains of faba bean (Viciafaba) collected from eastern and western Hararghe highlands of Ethiopia. Ethiop. J.Nat. Resour. 11 (2): 223-244.
O' Hara, G., Yates, R. and Howiesen, J. (2002). Selection of strains of root nodule bacteria to improve inoculant performance and increase legume productivity in stressful environments. In: D. Herridge

(Ed.), Inoculants and Nitrogen Fixation of Legumes in Vietnam.

Somasegaran P. and Hoben H.J. (1994). Hand book for Rhizobia. Method in Legume Rhizobium Technology. Springer-Verlag, New York.

Steel R. G. B. and Torrie J. H. (1980). Principles and Procedures of statistics. A Biometric Approach, $2^{\text {nd }}$ ed. McGraw-Hill, New York.

Surange S, Wollum AG, Kumar N, Nautiyal CS (1997) Characterization of Rhizobium from root nodules of leguminous trees growing in alkaline soils. Can J Microbiol 43:891-894

Workalemahu A. (2009). The effect of indigenous root- nodulating bacteria on nodulation and growth of faba bean (ViciaFaba)in the low-input agricultural systems of Tigray Highlands, Northem Ethiopia.Mol. Rev.63:968-989.

ZahranH.H.(1999). Rhizobiumlegumesymbiosisandnitrogenfixationunderseverec onditionsandin anacidclimate.Microbiol.Mol.Biol.Rev.63:968-9.

Zahran, H. H. (2001) Rhizobia from wild legumes: Diversity, taxonomy ecology, nitrogen fixation and biotechnology. J.Biotechnol 91: 143.153.

Zahran, H. H., Abdel-Fattah, M., Yasser, M. M., Mahmoud, A. M., and Bedmar, E. J. 2012. "Diversity and Environmental Stress Responses of Rhizobial Bacteria from Egyptian Grain Legumes." Australian Journal ofBasic and Applied Sciences 6 (10): 571-583.

Zakhia F, de Lajudie $P$ (2001). Taxonomy of rhizobia, Agronomie 21:569-576.

Zheng C, Jing F, Liu T, Dai Q, Jing cao w (2009). Effects of salat and water logging stresses and their combination on leaf photosynthesis, chloroplast ATP synthesis and antioxidant capacity in wheat. Plant Sci. 176:575-582 


\section{عزل وتعربف سلالات الريزوييا من العقد البكتيرية للفول البلدى}

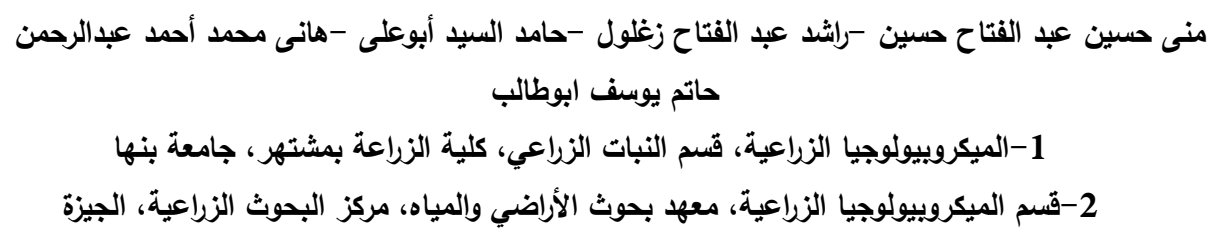

لتعظيم إنتاجية محصول الفول البلاى فى الأراضى المستصلحة حديثاً لجمهورية مصر العربية هناك احتباج لعزل سلالات ريزوبيا جديدة ونشيطة للإستخدام لمثل هذه الأراضى.

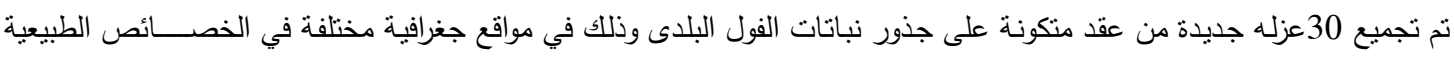

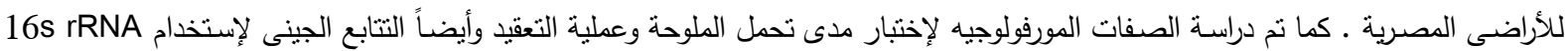

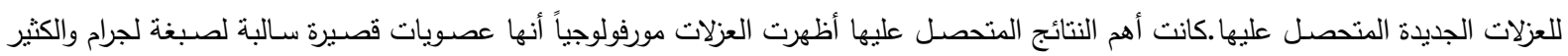

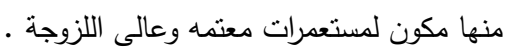

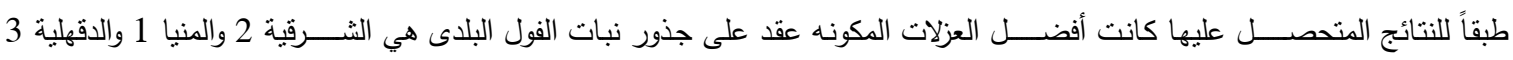

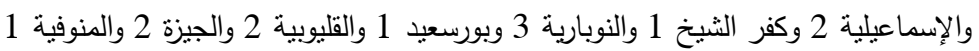
وتراوحت أعداد العقد المتكونة من 28 إلي 63 عقدة لكل نبات والوزن الجاف تراوح من 178 إلي 574 مللى جرام

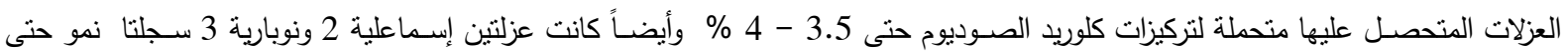

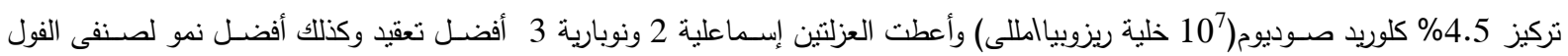
البلاى تحت ظروف الإختبار .

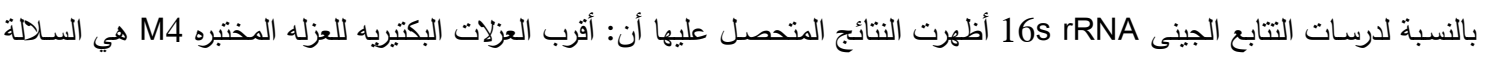

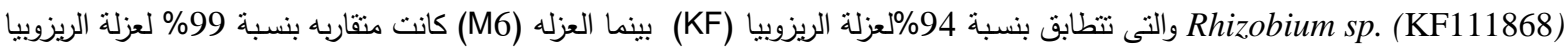
Rhizobium rubi (BBJU0100046)

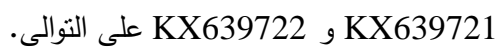

